PIOTR SYKUT

Warszawa

\title{
PRÓBY PRZEDZIERANIA SIĘ DROGĄ MORSKĄ PRZEZ NIEMIECKĄ BLOKADE POLSKIEGO WYBRZEŻA 1 IX - 2 X 1939 ROKU
}

Celem artykułu jest próba ukazania przedzierania się drogą morską przez niemiecką blokadę polskiego Wybrzeża w czasie działań wojennych w I939 r. Temat ten nie doczekał się dotychczas szerszego opracowania wykorzystującego relacje obrońców Wybrzeża, które znajdują się w różnych archiwach jak np. Archiwum Muzeum Marynarki Wojennej w Gdyni lub Archiwum Instytutu Polskiego i Muzeum im. gen. Sikorskiego w Londynie ${ }^{\mathrm{I}}$.

W czasie wojny w I939 r. obrońcy polskiego Wybrzeża zostali bardzo szybko odcięci przez oddziały niemieckie od reszty sił polskich. Jedyną możliwością wydostania się z Wybrzeża była droga morska lub powietrzna. Okręty Kriegsmarine i samoloty Luftwaffe, patrolując wody i przestrzeń powietrzną wokół polskiego Wybrzeża, miały uniemożliwić próby przedarcia się z terenu objętego walkami na wolność. Mimo to we wrześniu i w październiku I939 r. podjęto szereg prób wydostania się drogą morską i powietrzną do państw neutralnych, a także powrotu do kraju.

W ostatnich dniach sierpnia I939 r. kilka polskich jachtów odbywało rejsy szkoleniowe po Bałtyku. Jachty te jako pierwsze po rozpoczęciu działań wojennych przedostały się przez niemiecką blokadę do Polski.

2 września 1939 r. wpłynął do Jastarni jacht ,Szkwał”, który odbywał rejs stażowy po Bałtyku z członkami Akademickiego Związku Morskiego. W skład załogi wchodzili kpt. Stanisław Jaxa-Bykowski i Edgar Engel oraz cztery kandydatki na jachtowych sterników morskich: Maria Chrzanowska, Zofia Reynoldówna, Anna Wojtaśkiewicz i Danuta Żołątkowska. Jacht, płynąc z Kopenhagi, znalazł się nad ranem 2 września 1939 r. na Zatoce Gdańskiej. Z jego pokładu zaobserwowano dymy nad Westerplatte, przelatujące samoloty i słyszano strzelające działa. Ponieważ na jachcie nie było radia, nie wiedziano o wybuchu wojny. Podejrzewając, że są to tylko ćwiczenia, załoga skierowała jacht do Jastarni, a nocą przepłynięto do Gdyni².

Na początku września I939 r. przez niemiecką blokadę polskiego Wybrzeża przedarł się jacht „Wojewoda Pomorski”, należący do oddziału Akademickiego Związku Morskiego w Gdańsku. Na jego pokładzie znajdowali się oprócz kpt. Józefa Sarnowicza: I oficer nawigator Sławomir Peszkowski (AZM Gdańsk), II oficer prowiantowy Jan Machnicki (AZM

\footnotetext{
Jedyną dotychczas próbą ujęcia tematu jest praca R. Niczko wydana w serii „Zeszyty Helskie”. Zob. R. Niczko, Ku wolności-ucieczki z Wybrzeża 1939 r., „Zeszyt Helski”, 14/2012.

2 W. Głowacki, Dzieje żeglarstwa polskiego, Gdańsk 1989, s. 370-371.
} 
Kraków), III oficer - bosman Henryk Kabat (AZM Gdańsk) oraz 6 żeglarzy z AZM, a wśród nich podch. rez. Jerzy Kluczkowski³

28 sierpnia 1939 r. jacht ten wraz z jachtem „Panna Wodna” znajdował się w Malmö, gdzie obaj dowódcy - kpt. Józef Sarnowicz i kpt. Kazimierz Lech - podjęli decyzję powrotu do Polski. Jachty miały płynąć razem, ale 29 sierpnia I939 r. „Panna Wodna” zniknęła z pola widzenia. I września 939 r. kpt. Józef Sarnowicz dowiedział się z radia o wybuchu wojny, o czym poinformował całą załogę. Następnego dnia jacht wpłynął po południu na Zatokę Gdańską, a załoga ubrana w kamizelki ratunkowe obserwowała nalot na Hel. Ponieważ wezwany z Gdyni na godz. 20.00 pilot nie przybył, kpt. Józef Sarnowicz spróbował podpłynąć do mola orłowskiego, ale po ostrzelaniu przez karabin maszynowy skierował jacht do portu w Gdyni. W tym czasie wiatr ustał i jacht zaczął dryfować do zewnętrznego mola. $\mathrm{O}$ godz. 23.00 dobił do falochronu, a na jego pokład wskoczyło kilku marynarzy z oficerem, który zabrał z mesy dokumenty jachtu, dokumenty osobiste i mapę. Po około 45 minutach oficer zwrócił dokumenty i zezwolił na przepłynięcie do basenu, w którym jacht stanął na boi o godz. $00.30^{4}$.

Jacht „Panna Wodna” również należący do oddziału Akademickiego Związku Morskiego w Gdańsku, który razem z jachtem ,Wojewoda Pomorski” wypłynął z Malmö w południe 28 sierpnia 1939 r. do Polski, dotarł do portu we Władysławowie już I września 1939 r. o godzinie 5.45. W skład załogi wchodzili kpt. Kazimierz Lech, jego zastępca Konstanty Klimaszewski, oficer prowiantowy Jan Zbrożyna, bosman Bolesław Bagiński i Gabriel Holickí.

Jedną z pierwszych udanych prób ucieczek drogą morską z Wybrzeża podjęło pięciu ludzi na jachcie „Strzelec II"ך należącym do Oddziału Morskiego Związku Strzeleckiego. Byli to dwaj członkowie Klubu Żeglarskiego „Gryf”, a jednocześnie pracownicy Warsztatów Portowych Marynarki Wojennej w Gdyni: Edward Skrzypek i Michał Przepierczyński, dwaj piloci portowi w Gdyni: kpt. ż.w. Jerzy Lewandowski i kpt. ż.w. Władysław Grabowski oraz mechanik Bruno Wyględacz ${ }^{8}$.

Edward Skrzypek i Michał Przepierczyński zostali zwolnieni z pracy w Warsztatach Portowych Marynarki Wojennej przed zajęciem Gdyni przez oddziały niemieckie. Obaj

\footnotetext{
J. Sarnowicz, Epitafium ku czci Wojewody Pomorskiego, „Morze”, 9/1974, s. 22.

4 Ibidem, s. 23; J. Iżycki, Na pokładzie „,Wojewody”, „Kierunki”, 35/1959, s. 7.

5 Podczas wchodzenia do portu we Władysławowie jacht zawadził kilem o kamienie przy omijaniu pływającej przeszkody, cumował o godz. 5.45, a o godz. 6.00 został przeholowany do mola rybackiego. Zob. W. Głowacki, op. cit., s. 369.

6 W. Głowacki, op. cit., s. 369.

7 Jacht ten należał do serii 26 jednostek typu „Konik Morski” zbudowanych w latach 1937-1939 w Stoczni Yachtowej w Gdyni. „Konika Morskiego” zaprojektował już w 1936 r. Leon Tumiłowicz, wzorując się na amerykańskich konstrukcjach jachtów. Miał on długość 9,60 m, szerokość 2,72 m, zanurzenie 1,53 m, wyporność 4,5 tony, a powierzchnia żagla wynosiła $40 \mathrm{~m}^{2}$. Zob. W. Głowacki, op. cit., s. 336 .

8 J. Lesiak, Kronika Jacht Klubu Morskiego „,Gryf” LPŻ w Gdyni (Archiwum Jacht Klubu Morskiego „Gryf”, s. 13-14); J. Lewandowski, Z marynarskich wspomnień kapitana ż.w. Jerzego Lewandowskiego. Dwie ucieczki, „Morze”, 2/1984, s. 28; J. Lewandowski, Dwie ucieczki i jedno storpedowanie, w: Ku chwale bandery, red. J. Miciński, Warszawa 1992, s. 148-149; R. Niczko, op. cit., s. 3; T. Olchowy, Jachtem przez blokade hitlerowska, „Bandera”, 2/1962, s. 12; M. Przepierczyński, Wspomnienia żeglarza, Michała Przepierczyńskiego na Obczyźnie, (Archiwum Jacht Klubu Morskiego „Gryf”, s. 2-3); J. Sieński, Ucieczka pod żaglami, „Dziennik Bałtycki”, 233/1996, s. 22; Wspomnienia na temat pierwszych dni II wojny światowej (wrzesień 1939 r.) na terenie Gdyni. Relacja na temat ucieczki jachtu ,, Strzelec 2” do Szwecji (Narodowe Archiwum Cyfrowe, sygn. 33-T-2651); Al., Powrót po pólwieczu. Ostatnia bandera II RP, „Gazeta Gdańska”, 10/1990; I segelbåt från Gdynia till svenska kusten, ,Arbetet”, 237/1939, s. 1.
} 
podjęli decyzję o nie pozostawaniu w Gdyni i wydostaniu się z miasta drogą morską. Władysław Grabowski i Jerzy Lewandowski pełnili funkcje oficerów portu, utrzymując łączność z centralą na Oksywiu. W nocy z I2 na I3 września I939 r. oddziały Lądowej Obrony Wybrzeża opuściły Gdynię wycofując się na Kępę Oksywską. Rano I3 września Władysław Grabowski i Jerzy Lewandowski zostali zwolnieni z pracy w Urzędzie Morskim. Wypłacono im trzymiesięczną pensję i polecono połaczyć się z wojskami polskimi lub z flota handlowa, która częściowo znajdowała się na wodach terytorialnych Szwecji ${ }^{9}$. Wtedy postanowili wydostać się z Gdyni drogą lądową przez las z ulicy Szczecińskiej na południe Polski lub drogą morską jachtem przez Bałtyk do Szwecji. W tym celu prosto z Urzędu Morskiego pojechali rowerami do basenu jachtowego, gdzie spotkali nieznanych im wcześniej Edwarda Skrzypka i Michała Przepierczyńskiego, przygotowujących się również do ucieczki jachtem. Wszyscy postanowili spotkać się ponownie wieczorem na jachcie „Strzelec II”, aby spróbować przedrzeć się do Szwecji i tam zaokrętować się na polski statek. Następnie Władysław Grabowski i Jerzy Lewandowski wrócili do mieszkania st. mech. Michała Nowakowskiego przy ul. Szczecińskiej 34, w którym mieszkali tymczasowo od chwili częściowego zniszczenia podczas nalotu ich mieszkania w Domu Pilota przy ul. Chrzanowskiego. Tam przygotowali się do ucieczki, pakując do plecaków bieliznę i żywność. Wieczorem zauważyli z okna mieszkania oddziały niemieckie i natychmiast rowerami pojechali ul. Leśną w kierunku morza. Po przybyciu do basenu jachtowego przyłączyli się do grupy około 20 mężczyzn mających zamiar przedrzeć się do Szwecji na motorówce „Delfin”. Na motorówce nie udało się uruchomić motoru, a w grupie uciekinierów nie było żadnego mechanika. Wrócili więc na jacht „Strzelec II”, na którym wraz z Edwardem Skrzypkiem i Michałem Przepierczyńskim zaczęli przygotowywać się do wypłynięcia z portu. Wtedy dołączył do nich Bruno Wyględacz - kolega szkolny Jerzego Lewandowskiego. Był z nimi jeszcze jeden człowiek, ale w ostatnim momencie zrezygnował, wyskakując na molo ${ }^{\mathrm{IO}}$. Po odcięciu cum rufowych, klucząc między innymi jachtami, „Strzelec II” zaczął wychodzić z basenu, kierując się na północno-wschodni cypel Zatoki Gdańskiej na Brüsterort. Pogoda sprzyjała uciekinierom, zapadła już noc, padał deszcz i wiał dość silny południowo-zachodni wiatr, a widoczność była ograniczona. Jacht był zalewany przez bryzgi fal. Najpierw wachtę przy sterze przez prawie całą noc pełnili Jerzy Lewandowski i Edward Skrzypek, a później zastąpili ich Władysław Grabowski i Michał Przepierczyński. Z obawy przed wykryciem nie włączono na jachcie świateł, jedynie Michał Przepierczyński palił jednego papierosa za drugim, aby oświetlić różę kompasową. Pogoda w końcu zaczęła się poprawiać, wiatr osłabł, a jacht zmienił kurs na północno-zachodni do szwedzkiego portu Karlskrona. Około południa, gdy wreszcie zza chmur wyszło słońce, a cała załoga leżała na pokładzie i suszyła ubrania, doszło do spotkania z niemieckim statkiem. Ponieważ jacht płynął pod banderą szwedzką, nie został zatrzymany. Problemów uniknięto dzięki Edwardowi Skrzypkowi, który zabrał na jacht banderę szwedzką i fińską. Po dwóch dniach rejsu członkowie załogi zobaczyli wreszcie w nocy światło latarni Utklippan. Na jachcie skończyła się już żywność, nafta do prymusa i zapałki. Gdy nad ranem jacht znalazł się w pobliżu Karlskrony, rzucono kotwicę i poproszono znajdującego się w pobliżu rybaka o wskazanie dokładnej drogi do portu.

\footnotetext{
J. Lewandowski, Z marynarskich wspomnień kapitana ż.w. Jerzego Lewandowskiego. Dwie ucieczki, „Morze”, 2/1984, s. 28.

10 Człowiekiem tym mógł być Józef Lesiak. Zob. T. Olchowy, op. cit., s. 20.
} 
Ten odmówił, informując, że tylko pilot może wprowadzić jacht, ale zaproponował pomoc w wezwaniu pilota przez telefon. Razem z rybakiem popłynął Jerzy Lewandowski, który zatelefonował do portu $\mathrm{z}$ domu rybaka. Został on zaproszony przez rodzinę rybaka na kawę i ciastka, a przed powrotem na jacht otrzymał butelkę nafty i zapałki. Po przybyciu pilota podniesiono kotwicę i jacht wpłynął do Karlskrony. W tym czasie załoga przygotowywała się do zejścia na ląd. Po zacumowaniu jachtu wszyscy zostali zatrzymani w miejscowym Posterunku Policji za nielegalne przekroczenie granicy, ponieważ nie posiadali wiz i paszportów. W czasie internowania jeździli na spacer samochodem naczelnika więzienia, a posiłki jadali w restauracji zawsze w towarzystwie policjanta po cywilnemu. Internowanie trwało 30 dni do momentu otrzymania paszportów z Ambasady Polskiej w Sztokholmie. Następnie zostali skierowani do Malmö, potem do Lund, gdzie zamieszkali w hotelu turystycznym, aż w końcu znaleźli się w Sztokholmie. W Ambasadzie Polskiej zostali poinformowani o przydzieleniu ich na motorowiec „Rozewie” płynący do Bergen. Po kilku dniach postoju w Bergen cała załoga jachtu ,Strzelec II” dotarła na pokładzie „Rozewia” płynącego w konwoju do Wielkiej Brytanii ${ }^{\text {I }}$.

Sukcesem zakończyła się również próba przedarcia się przez linie niemieckiej blokady morskiej polskiego Wybrzeża podjęta przez grupę oficerów Polskiej Marynarki Wojennej na kutrze „Gdy 55” - „Albatros”, ${ }^{\prime 2}$, który wyruszył z Babiego Dołu I3 września wieczorem około godz. 20.00, już po zapadnięciu zmroku. Na jego pokładzie znajdowali się kmdr por. Stanisław Hryniewiecki, kpt. mar. Wiktor Łomidze, były zastępca dowódcy stawiacza min ORP „Gryf”, por. mar. Stanisław Pohorecki, adiutant Hryniewieckiego, por. mar. Jerzy Koziołkowski, oficer z zapasowej załogi Dywizjonu Okrętów Podwodnych, pełniący obowiązki zastępcy oficera sygnałowgo Floty, por. mar. inż. Stanisław Radogost-Uniechowski, oficer korpusu technicznego zatrudniony wtedy w Warsztatach Portowych Marynarki Wojennej na Oksywiu, dwóch marynarzy st. mar. A. Wiśniewski i J. Jarema oraz właściciele kutra, bracia Karol i Paweł Krüger ${ }^{13}$.

Inicjatorem tej wyprawy był kmdr por. Stanisław Hryniewiecki pełniący funkcję przedstawiciela kadm. Józefa Unruga przy płk. Stanisławie Dąbku, dowódcy Lądowej Obrony

\footnotetext{
11 J. Lesiak, op. cit., s. 13-14; J. Lewandowski, Z marynarskich wspomnień kapitana ż.w. Jerzego Lewandowskiego. Dwie ucieczki, „Morze”, 2/1984, s. 28-29; idem, Dwie ucieczki i jedno storpedowanie, w: Ku chwale bandery, red. J. Miciński, Warszawa 1992, s. 148-151; T. Olchowy, op. cit., s. 12; M. Przepierczyński, op. cit., s. 2-5; J. Sieński, op. cit., s. 22; Wspomnienia na temat pierwszych dni II wojny światowej (wrzesień 1939 r.) na terenie Gdyni. Relacja na temat ucieczki jachtu ,Strzelec 2” do Szwecji (Narodowe Archiwum Cyfrowe, sygn. 33-T-2651); Al., Powrót po pótwieczu. Ostatnia bandera II RP, ,Gazeta Gdańska”, 10/1990. Według M. Twardowskiego uciekinierzy zabrali ze sobą jako prowiant tylko walizkę pomarańczy. Zob. M. Twardowski, Jacht Klub Morski ,, Gryf”, Gdynia 2008, s. 17.

12 „Gdy 55” - „Albatros” kuter drewniany zbudowany w 1935 r. w stoczni Rybackiej w Gdyni, długość 16,45 m, szerokość 5,03 m, data rejestracji 05.01.1937 r. Zob. B. Huras, M. Twardowski, Księga statków polskich 19181945, t. 4, Gdańsk 2002, s. 32; W. Blady, Polska flota rybacka w latach 1921-2001, Gdynia 2002, s. 12.

13 Ĕ. Jēkabsons, Materiały o internowanych polskich żotnierzach na Łotwie 1939-1940 w Państwowym Archiwum Historycznym Łotwy, „Białostocczyzna”, 2/1999, s. 79-80; Е̌. Jēkabsons, Internowanie żołnierzy polskich na Łotwie w latach 1939-1940, http://www.wyklady.ekpu.lublin.pl/wyklady/jekabsons/jekabsonsw4.htm (15.01.2013); J. Koziołkowski, Załącznik do zeszytu ewidencyjnego. Meldunki o znanych działaniach wojennych (Archiwum Instytutu Polskiego i Muzeum im. gen. Sikorskiego, MAR. A. II. 5/1A, s. 26); J. Pertek, Jak przerywano blokadę na Helu, „Morze”, 10/1959, s. 26; idem, Mała flota wielka duchem, Poznań 1989, s. 95-97; S. Pohorecki, Zerwana tajemnica, „Nasze Sygnały”, 145/1980, s. 11; J. Tuliszka, Komandor porucznik Stanisław Hryniewiecki (18961943), „Biuletyn Historyczny”, 16/1999, s. 196; B. Wroński, Fakt historyczny, którego nie było, „Nasze Sygnały”, $146 / 1981$, s. $16-19$.
} 
Wybrzeża, jako oficer do specjalnych zleceń. Prawdopodobnie zdając sobie sprawę, że na Półwyspie Helskim nie otrzyma żadnego konkretnego przydziału, zwrócił się do kadm. Józefa Unruga o zezwolenie na podjęcie próby przedarcia się kutrem przez niemiecką blokadę do Łotwy ${ }^{\mathrm{I4}}$.

Jeszcze przed uzyskaniem zgody kadm. Józefa Unruga kmdr por. Stanisław Hryniewiecki zaproponował wzięcie udziału w wyprawie byłemu zastępcy dowódcy stawiacza min ORP „Gryf” kpt. mar. Wiktorowi Łomidze, lekko rannemu 3 września i ewakuowanemu wraz z innymi rannymi z Helu do szpitala w Gdyni. Kpt. mar. Wiktor Łomidze dowiedział się o zamiarze opuszczenia Gdyni w nocy z I2 na I3 września przez oddziały Lądowej Obrony Wybrzeża. Ponieważ nie chciał dostać się do niewoli, kazał się wypisać ze szpitala, a następnie zameldował się w Gdyni u kmdr. por. Stanisława Hryniewieckiego. Nie otrzymał żadnego przydziału, ponieważ rana była jeszcze niezagojona ${ }^{15}$. W swojej relacji tak wspomina podjęcie decyzji o wzięciu udziału w wyprawie:

Sytuacja przedstawiała się beznadziejnie. Poddanie się Oksywia wobec niemożności dalszej obrony było kwestia paru dni, a więc znowu perspektywa trafienia do niewoli. Nie majac żadnego przydziału, zgodziłem się na propozycję. Pojechaliśmy do Babiego Dołu, gdzie otrzymaliśmy telefoniczne zezwolenie D-cy Floty na tę imprezę z tym, żeby wziąć jak najwięcej oficerów marynarki ${ }^{16}$.

Na taką propozycję kmdr. por. Stanisława Hryniewieckiego zgodził się również por. mar. Jerzy Koziołkowski, który II września wieczorem przewiózł kutrem amunicję z Jastarni do Babiego Dołu dla oddziałów Lądowej Obrony Wybrzeża. Przewożenie amunicji było już wtedy utrudnione ze względu na patrolujące w Zatoce Gdańskiej niemieckie kutry i niechęć Kaszubów, właścicieli kutrów, do podejmowania tak ryzykownych wypraw ${ }^{17}$.

Czekając na kuter mający zawieźć go z powrotem na Hel, por. mar. Jerzy Koziołkowski spędził cały dzień I2 września w towarzystwie swojego kolegi z rocznika por. mar. Mieczysława Kobierzyckiego, będąc świadkiem ewakuacji miasta i likwidacji odcinków broniacych miasta $^{18}$. W nocy z I2 na I3 września opuścił Gdynię wraz z wycofującymi się oddziałami Lądowej Obrony Wybrzeża na Oksywie. Następnie poinformował Dowództwo Floty na Helu, że nie może wrócić na Półwysep Helski z powodu braku kutra' ${ }^{19}$. W swojej relacji tak wspomina dzień I3 września, który spędził na Oksywiu:

Po potudniu nadszedt telefon z Babiego Dotu od Hryniewieckiego, wzywajacy Uniechowskiego, Siwickiego i mnie do wykonania specjalnego zadania (z poleceniem zabrania wszystkich rzeczy). Nie miatem najmniejszej intencji do wykonywania specjalnych zadań, chciałem wracać na Hel, po drodze miałem zawieźć komisarza Sokoła

14 J. Pertek, Mała flota wielka duchem, Poznań 1989, s. 95-96; J. Tuliszka, op. cit., s. 196.

5 B. Wroński, op. cit., s. 18.

6 Cyt. za: B. Wroński, op. cit., s. 18.

17 J. Koziołkowski, op. cit., s. 26. Według J. Netzla amunicja była dostarczana kutrami z Jastarni do Babiego Dołu do 18 września 1939 r. Zob. J. Netzel, Kutrem na wojnę (fragmenty wspomnień), „Rocznik Gdyński”, 10/1991, s. 342. Na temat dostarczania amunicji kutrami z Jastarni do Babiego Dołu pisze również w swoich wspomnieniach J. Glembin. Zob. J. Glembin, Pracuję na kutrze „Arki”, Gdańsk 1951, s. 20-21. O komunikacji z Oksywiem pisze również w swoich wspomnieniach W. Steyer. Zob. W. Steyer, Samotny półwysep, Poznań 1983, s. 49.

18 J. Koziołkowski, op. cit., s. 26.

19 B. Wroński, op. cit., s. 18. 
i personel Infu na Hel - namawiatem Kobierzyckiego, by jechat też do Babiego Dołu, nie chciat. Ponieważ Siwicki byt zajęty przygotowaniem blach na samochody pancerne, zostat więc Uniechowski, postarat się o samochód i namówit mnie na wcześniejszy wyjazd ${ }^{20}$.

Po przyjeździe do Babiego Dołu dowiedzieli się w czasie spotkania nad morzem z kmdr. por. Stanisławem Hryniewieckim o przyczynie ich wezwania. Zamiarem oficerów było przedostanie się morzem do jakiegoś portu neutralnego, a następnie z powrotem do kraju, aby prowadzić walkę z wrogiem ${ }^{21}$. W Babim Dole znajdowały się już dwa kutry zarekwirowane wcześniej i sprowadzone z Redy mimo niemieckiego ostrzału przez por. mar. Stanisława Pohoreckiego.

Warunki atmosferyczne panujące I3 września I939 r. sprzyjały podjęciu wyprawy kutrem: szybko zapadający zmrok, zachmurzone niebo, padający deszcz, dość silny wiatr i fala. Około godz. 20.00 na kutrze podniesiono kotwicę, uruchomiono motor i wyruszono w morze, kierując się początkowo na Hel, a później na północ. Podczas wychodzenia w morze załoga kutra obserwowała łuny pożarów powstałe od palących się okolicznych wsi. Kuter płynął bez świateł, aby utrudnić wykrycie go przez patrolujące jednostki niemieckie. W tym celu wcześniej wyjęto żarówki ze świateł na pokładzie, a por. mar. Jerzy Koziołkowski po wdrapaniu się na maszt, uderzeniem młotka rozbił światło topowe ${ }^{22}$.

Najlepiej przebieg rejsu oddaje relacja jednego z uczestników wyprawy - por. mar. Jerzego Koziołkowskiego:

Około godz. 22.00 byliśmy koło Helu - ciemne zarysy pótwyspu przesunęty się koło nas $i$ zniknęty $w$ deszczu. Otulony płaszczem gumowym i kocem usadowiłem się na dziobie kutra „na oku”. Szliśmy na Nord z zamiarem dojścia do Hoborgu. Motor hałasowat niemożliwie. Od czasu do czasu z rury wydechowej sypały się iskry. Przechodziliśmy przez miejsce, $w$ którym [polskie] okręty podwodne stawiaty miny (zanurzenie kutra trzy metry, miny również byly na trzech metrach), zaś cała zatoka pełna była kutrów pościgowych i traulerów. Wychodziliśmy w środę 13 września. Siedziatem „na oku" cała noc do rana, przemoknięty do nitki, zmarznięty na kość, wytężając wzrok, czy nie spotkamy kogoś po drodze. Szczęście sprzyjało. W nocy spotkaliśmy dwa parowce idace ze światłami, minęliśmy [je] w dużej odległości. Rano, zmęczony do ostateczności, rzuciłem się spać (trzy noce prawie bez spania). Zbudziłem się po południu. Pogoda przez cały czas była jak najlepsza dla nas. Silna fala, słaba widoczność. W międzyczasie zmieniliśmy kurs: po odejściu kilkudziesięciu mil na Nord od Helu Hryniewiecki zdecydowat się iść nie do Szwecji, a do Lipawy ${ }^{23}$.

W trakcie rejsu, już po dokonaniu zwrotu na Lipawę, nagle stanął motor kutra, którego początkowo nie mogli uruchomić nawet właściciele kutra, bracia Karol i Paweł Krüger.

\footnotetext{
20 Cyt. za: B. Wroński, op. cit., s. 19.

21 J. Koziołkowski, op. cit., s. 26; B. Wroński, op. cit., s. 19. Według wspomnień S. Pohoreckiego, kadm. J. Unrug rozkazał kmdr. por. S. Hryniewieckiemu popłynąć do Tallina z zadaniem uwolnienia z internowania okrętu podwodnego ORP „Orzeł”. Wersja ta jest nieprawdziwa, co udowodnił w swoim artykule B. Wroński. Zob. S. Pohorecki, op. cit., s. 11; B. Wroński, op. cit., s. 16-20.

22 J. Koziołkowski, op. cit., s. 26; S. Pohorecki, op. cit., s. 11; B. Wroński, op. cit., s. 18-19.

23 Cyt. za: J. Pertek, op. cit., s. 97-98.
} 
Podniesiono żagle, ale po godzinie Kaszubi naprawili motor i ruszono w dalszą drogę. Po zapadnięciu zmroku załoga kutra dostrzegła ciemny pas lądu, sonda pokazała głębokość 5m i wreszcie o godz. 22.00 kuter „Gdy 55” - „Albatros”, wpłynął do portu w Lipawie, w którym stanął na kotwicy. Polacy zostali internowani, kuter skonfiskowano, a dwaj jego właściciele zostali na własną prośbę zwolnieni i odesłani do Gdyni ${ }^{24}$.

Kmdr por. Stanisław Hryniewiecki, kpt. mar. Wiktor Łomidze i por. mar. inż. Stanisław Radogost-Uniechowski po wielu przejściach dotarli 3 stycznia 1940 r. do Wielkiej Brytanii, a por. mar. Stanisław Pohorecki i por. mar. Jerzy Koziołkowski znaleźli się tam już wcześniejej.

W połowie ostatniej dekady września miała miejsce udana ucieczka co najmniej czterech ludzi na pokładzie kutra rybackiego, który wypłynął wieczorem z Helu. Był to duński kuter rybacki, który z powodu awarii motoru i wybuchu wojny pozostał opuszczony przez załogę w porcie handlowym. Inicjatorem wyprawy był st. mar. Jacek Tracz, który pełnił funkcję łącznika motocyklisty w plutonie ochrony na Helu. O planie ucieczki poinformował dowódcę Rejonu Umocnionego Hel kmdr. Włodzimierza Steyera. W skład załogi kutra wchodzili st. mar. Jacek Tracz oraz Szarmach, Konka i Szyberski. W czasie rejsu kuter został nawet zatrzymany przez trałowiec niemiecki w pobliżu Bornholmu, ale posiadał banderę duńską i dokumenty, ciągnął również sieć w której były dorsze. Niemcy sprawdzili dokumenty, dostali świeże ryby i odpłynęli, niczego nie podejrzewając. Kuter ten, mijając wcześniej wyspy Olandię i Gotlandię, dopłynął 2 października do brzegów Łotwy, gdzie zmieniono banderę duńską na radziecką, a następnie wpłynął do jednego z portów łotewskich, w którym załoga, nie zwracając na siebie uwagi, wysiadła ${ }^{26}$.

W godzinach rannych I października I939 r. na Helu odbyła się narada u dowódcy Floty kadm. Józefa Unruga. Udział w niej wzięli: dowódca Morskiej Obrony Wybrzeża kmdr dypl. Stefan Frankowski, dowódca Rejonu Umocnionego Hel kmdr Włodzimierz Steyer i szef sztabu Dowództwa Floty kmdr Marian Majewski²7.

\footnotetext{
24 S. Pohorecki, op. cit., s. 11-12; B. Wroński, op. cit., s. 19. Według S. Pohoreckiego po odesłaniu do Gdyni braci Karola i Pawła Krügerów został zwolniony na jego własną prośbę st. mar. Wiśniewski i również odesłany do Gdyni. Zob. S. Pohorecki, op. cit., s. 12. Jak podaje J. Pertek, Karol Krüger zmarł w czasie okupacji, a Paweł po otrzymaniu od władz niemieckich polskiego kutra pływał na nim do 1945 r. W 1945 r. ewakuował kutrem żołnierzy niemieckich z Gdyni na Hel, po czym został powieszony na Helu za odmowę wykonania jakiegoś rozkazu. Zob. J. Pertek, op. cit., s. 99. Według Ĕ. Jēkabsonsa brat Karola Krügera miał na imię Henryk. Zob. Ě. Jēkabsons, Internowanie żotnierzy polskich na Łotwie w latach 1939-1940, http://www.wyklady.ekpu.lublin.pl/wyklady/jekabsons/jekabsonsw4.htm (15 01 2013). Zdaniem autora kuter „Gdy 55” - „Albatros” jest prawdopodobnie kutrem, o ucieczce którego wspomina nieznany autor w relacji opisującej rybołóstwo w latach 1939-1945, na którego następnie powołuję się A. Ropelewski albo informacje te dotyczą kutra J. Dency „Gdy 2”, który według relacji rybaka P. Bukowskiego wchodził w skład Oddziału Kutrów, a następnie został zabrany przez polskich żołnierzy do Rygi i wrócił na Wybrzeże sprowadzony przez Niemców. Zob. B. Huras, M. Twardowski, op. cit., s. 75; Rybołówstwo w latach 1939 - 1945, „Tygodnik Morski”, 13/1962, s. 7; A. Ropelewski, Rybołówstwo na wybrzeżu gdańskim w latach okupacji (1939-1945), ,Studia i Materiały do Dziejów Wielkopolski i Pomorza”, t. 9, 1966, z. 1, s. 83.

25 J. Pertek, op. cit., s. 100-102; J. Tuliszka, op. cit., s. 197. Oczywiście nieprawdziwe jest stwierdzenie w artykule E. Juśki, o por. mar. J. Koziołkowskim, że...kutrem rybackim „Albatros”, poprzez cieśniny duńskie i Morze Północne doptynąt do Szwecji, a potem do Anglii. Zob. E. Juśko, Komandor por. Jerzy Koziołkowski (1911-1990). Tarnowski dowódca jednego ze „,Strasznych bliźniaków”, „Tarnowskie Studia Historyczne”, t. 1, 2009 , s. 127.

26 W. Steyer, op. cit., s. 111-115; J. Tetter, Bitwy II wojny światowej. Polskie Termopile, „Głos Wybrzeża”, 158/1969, s. 5.

27 J. Unrug, Przemówienie adm. Unruga, „Nasze Sygnały”, 95/1959, s. 11.
} 
Kadm. Józef Unrug poinformował zebranych, że podjął decyzję o kapitulacji ze względu na to, że dalsza walka mogła być prowadzona nie dłużej jednak jak 5 do Io dni ze względu na brak amunicji artyleryjskiej, a zwłaszcza przeciwlotniczej i spowodowałaby duże straty w załodze RU Hel. Ponadto warunkiem dalszego kontynuowania walki było zażegnanie możliwości dalszych buntów w oddziałach RU Hel, co było związane z rozlewem krwi, do którego nie chciał dopuścić. W tym czasie Hel stracił także znaczenie jako baza dla floty, której okręty zostały zatopione, internowane albo opuściły Bałtyk ${ }^{28}$.

W wyniku decyzji o kapitulacji RU Hel podjęte zostały następne próby przedarcia się przez niemiecką blokadę.

Niepowodzeniem zakończyła się próba ucieczki łodzią rybacką z Jastarni podjęta w dniu I października I939 r. przez ppor. mar. rez. Jędrzeja Giertycha, ppor. mar. rez. Andrzeja Goebla, ppor. mar. rez. Henryka Borakowskiego, st. mar. Bolesława Nowakowskiego oraz dwóch nieznanych marynarzy. Wszyscy wchodzili w skład kompanii przeciwdesantowej stacjonującej w Jastarni pod dowództwem kpt. mar. rez. Alfreda Jougana ${ }^{29}$. Jeszcze przed ogłoszeniem zawieszenia broni wszyscy trzej oficerowie podjęli decyzję, że nie pójdą do niewoli i będą starali się przedostać łodzią wiosłową przez Bałtyk do Szwecji. Postanowili uciekać łodzią prosto z plaży, ponieważ wzięcie motorówki z portu położonego od strony zatoki spowodowałoby konieczność płynięcia wielu kilometrów wzdłuż brzegu Półwyspu Helskiego, zanim wypłynęliby na otwarte morze ${ }^{30}$. Po uzyskaniu zgody kpt. mar. rez. Alfreda Jougana przystąpili do organizacji wyprawy. Zaproponowali udział w ucieczce trzem marynarzom z kompanii przeciwdesantowej, którzy zgodzili się wziąć udział w tej wyprawie. Czterech ludzi miało wiosłować, jeden sterować, a jeden w tym czasie spać. Niedużą, lekką, płaskodenną łódź wiosłową używaną do połowu węgorzy mieli już od dawna upatrzoną, ale nie znali jej właściciela. Ppor. mar. rez. Jędrzej Giertych wręczył pieniądze znajomej rodzinie kaszubskiej z prośbą o odszukanie właściciela łodzi i przekazanie mu pieniędzy. Za pośrednictwem syna tej rodziny zakupił cztery wiosła ${ }^{31}$. W swoich wspomnieniach ppor. mar. rez. Jędrzej Giertych tak przedstawia przygotowania do ucieczki:

Baryłkę do wody, pływająca kotwicę żagiel (na wypadek gdyby było możliwe nim się postużyć), pasy ratunkowe, trochę lin - wzięliśmy ze stacji ratowania tonacych okrętów. Żal nam było, że nie możemy wziąć z tej stacji łodzi ratowniczej; ta wspaniała łodzia moglibyśmy nie tylko my, ale i cała gromada innych przeprawić się bezpiecznie przez Battyk. Ale tak ogromnym pudtem nie sposób byłoby się przemknąc niepostrzeżenie przez linię blokady.

Niestety załoga łodzi nie posiadała żadnych map i zamierzała kierować się jedynie za pomocą kompasu IOo km na północ, a po zrobieniu zwrotu w kierunku północno-zachodnim płynąć aż do osiągnięcia brzegów Szwecji. Zaopatrzono się również w żywność, którą pobrano z zasobów wojskowych. Podczas oczekiwania na zmierzch załoga łodzi była świadkiem

28 Ibidem, s. 11.

29 H. Borakowski, Spetnione marzenia, w: Ku chwale bandery, red. J. Miciński, Warszawa 1992, s. 51; J. Giertych, Wrześniowcy. Opowieść, Londyn 1957, s. 50-51; B. Nowakowski, Wspomnienia z okresu wojny i okupacji (Archiwum Muzeum Marynarki Wojennej, dalej - AMMW, sygn. 166, s. 5).

30 J. Giertych, op. cit., s. 50.

31 Ibidem, s. 51.

32 Ibidem, s. 51. 
zatonięcia niemieckiego trałowca M-85 na minie postawionej przez polski okręt podwodny ORP „Żbik”. Kiedy zapadła noc, załoga przeniosła łódź z wydmy na plażę i włożyła do środka swoje rzeczy. Następnie po zdjęciu płaszczy i marynarek tylko w samych swetrach, spodniach i butach weszła do wody, spychając łódź z plaży do wody. Pomagała im grupa kilkunastu marynarzy z Jastarni, prowadząc łódź po wodzie i podpierając jej burty33. Łodzią sterował ppor. mar. rez. Henryk Borakowski. Ponieważ fala przybojowa była bardzo silna i odrzucała łódź z powrotem na brzeg, pomagający marynarze musieli kilkakrotnie ponawiać próbę przeprowadzenia łodzi na głębszą wodę. Gdy łódź znalazła się już daleko od brzegu, została zepchnięta przez falę tak, że stanęła do niej burtą. W wyniku takiego ustawienia łódź przewróciła się do góry dnem, a ppor. mar. rez. Jędrzej Giertych, ppor. mar. rez. Andrzej Goebel i ppor. mar. rez. Henryk Borakowski oraz trzej marynarze wpadli do wody. Nikt nie utonął i nie został ranny. Wszyscy dopłynęli do brzegu wpław. Łódź została wyrzucona przez falę na brzeg. Załoga wyciągnęła ją na plażę, a następnie zaczęła zbierać rzeczy wyrzucone przez morze na brzeg. Niektóre rzeczy zdołano uratować m.in. Jędrzej Giertych odnalazł portfel z fotografiami żony i dzieci oraz dokumenty. Stracono zapasy żywności ${ }^{34}$. Było już późno, gdy całkowicie przemoczeni i zziębnięci oficerowie dotarli na swoją kwaterę, gdzie w jednym z pensjonatów odbywała się pożegnalna kolacja, w której uczestniczyła większość oficerów z garnizonu Jastarnia. Po przebraniu się zjedli kolację, a następnego dnia po kapitulacji RU Hel trafili do niewoli ${ }^{35}$.

Najbardziej znaną i udaną próbą przerwania niemieckiej blokady Helu była ucieczka do Szwecji kutra pościgowego Straży Granicznej „Batory”36. Organizatorem i dowódcą wyprawy był kierownik Referatu Radiowego Szefostwa Służby Łączności Komendy Portu Wojennego w Gdyni, kpt. Jerzy Milisiewicz ${ }^{37}$. To on właśnie przedstawił pomysł wydostania się z Helu na ścigaczu „Batory” kadm. Józefowi Unrugowi, który po południu I października udzielił ogólnego zezwolenia wszystkim, którzy chcieli i mogli się wydostać z Helu ${ }^{38}$. Razem z kpt. Jerzym Milisiewiczem udział w wyprawie wzięło 6 oficerów: zaprzyjaźniony z nim kpt. mar. Konrad Sawicz-Korsak (oficer sygnałowy Dowódcy Floty), kpt. mar. Eligiusz Ceceniowski (dowódca trałowca „Czajka”), por. mar. Tadeusz Męczyński (II oficer artyleryjski

\footnotetext{
33 Według relacji B. Nowakowskiego jednym z pomagających marynarzy był chor. Wojtkowiak. Zob. B. Nowakowski, op. cit., s. 5.

34 H. Borakowski, op. cit., s. 51; J. Giertych, op. cit., s. 51-53;

35 J. Giertych, op. cit., s. 53; Z. Boczkowski, Miny za burta, Warszawa 1975, s. 113. Z. Boczkowski mylnie podaje, że jednym z uciekinierów był ppor. mar. rez. T. Pocełujew. Zob. Z. Boczkowski, op. cit., s. 113.

36 „Batory” - kuter pościgowy Straży Granicznej zbudowany w Stoczni Modlińskiej. Rozpoczęcie budowy nastąpiło pod koniec 1930 r., wodowanie 23 kwietnia 1932 r., a ukończenie 7 maja 1932 r. Wyporność 26,5 t std., po 1933 r. 28 t. Długość całkowita 21,2 m, szerokość 3,6 m, wysokość 2,25 m, zanurzenie 1,1-1,35 m. Napęd 2 silniki 12 cylindrowe benzolowe Maybach o mocy 550 KM każdy i 1 silnik 6 cylindrowy Diesel również firmy Maybach o mocy 175 KM. Uzbrojenie $2 \mathrm{ckm}$ Maxim $08 \mathrm{kal}$. 7,9 mm. Prędkość max. 24,32 węzła. Załoga 9 ludzi. Zob. I. Bieniecki, Jednostki pływajace polskich formacji ochrony granicy morskiej w latach 1918-1939, w: 80 rocznica powstania Straży Granicznej II Rzeczypospolitej, red. A. Gosławska-Hryhorczuk, Warszawa-Kętrzyn 2008, t. 2, s. 62-63; M. Filipowicz, Ludzie, statki i okręty, Gdańsk 1985, s. 39; M. Kuligiewicz, Kuter pościgowy Batory, Warszawa 1974, s. 7; B. Huras, M. Twardowski, op. cit., s. 240. Według B. Hurasa i M. Twardowskiego niektóre źródła podają, że „Batory” uzbrojony był w 3 ckm. Zob. B. Huras, M. Twardowski, op. cit., s. 240.

37 J. Milisiewicz wspomina w swojej relacji, że planował najpierw ucieczkę łodzią 6-wiosłową, a w dniu $1 \mathrm{X}$ 1939 r. próbował uruchomić silnik na statku dozorczym ochrony rybołówstwa „Kania”. Próba ta wskutek wypuszczenia sprężonego powietrza zakończyła się niepowodzeniem. Zob. J. Milisiewicz, Pamiętnik przeprawy na kutrze „Batory” $i$ wspomnienia z internowania w Szwecji 1939-1943, „Biuletyn Historyczny”, 21/2006, s. 84.

38 J. Unrug, op. cit., s. 11.
} 
na stawiaczu min „Gryf”), por. mar. Alfons Górski i ppor. mar. Mieczysław Tarczyński (pomocnik oficera sygnałowego Dowódcy Floty). Na kutrze oprócz oficerów znajdowali się także mat Alfred Chęciński, starsi marynarze Stanisław Kwiatkowski, Henryk Pull, Antoni Słomiński i mar. rez. Witold Hubert. Udział w wyprawie wzięli także trzej marynarze ze stałej załogi „Batorego”, mianowicie II motorzysta ścigacza mat Roch Kaźmierczak, kpr. Straży Granicznej Jan Gawlik i radiotelegrafista Stanisław Lis oraz dwóch urzędników kontraktowych Dowództwa Floty: Kazimierz Sokołowski i Stanisław Nikiel. Razem na ścigaczu „Batory” znalazło się I6 ludzi ${ }^{39}$.

Na kutrze zamierzał wydostać się z Helu również kpt. Bolesław Żarczyński, dowódca 2 Morskiego Plutonu Żandarmerii na Helu, ale gdy przebywał na pokładzie ścigacza, żandarm pełniący służbę przy wejściu na molo zameldował, że jest on wzywany do telefonu znajdującego się w budce wartownika. Telefonował dowódca Rejonu Umocnionego Hel kmdr Włodzimierz Steyer, który polecił kpt. Bolesławowi Żarczyńskiemu zorganizowanie $\mathrm{z}$ podległych mu żandarmów służby policyjno-porządkowej w Helu, ponieważ otrzymał informacje o rabunkach dokonywanych przez marynarzy. Następnie po dotarciu do kwatery plutonu wysłał znajdujących się tam około Io żandarmów na patrolowanie wsi i wrócił do portu, ale „Batory” już odpłynął ${ }^{40}$.

Kpt. Jerzy Milisiewicz planował wyruszyć o godz. I8.00, ale por. mar. Tadeusz Męczyński nie przywiózł benzyny z portu wojennego. $\mathrm{Na}$ „Batorym” była tylko ropa do silnika Diesla. Potrzebną benzynę przepompowano z motorówki Straży Granicznej „Mazur” i kuter wypłynął I października I939 r. o godz. $19 \cdot 40^{4 \mathrm{I}}$.

„Batory” po wyjściu z portu rybackiego i opłynięciu cypla Półwyspu Helskiego rozwinął prędkość marszową I5 węzłów, płynąc na silnikach benzolowych, kursem $45^{\circ}$, w kierunku północno-wschodnim. Przy sterze stał kpt. Jerzy Milisiewicz, który posiadał dyplom kapitana żeglugi jachtowej i pływając na jachtach, był kilka razy w Szwecji, a także znał nawet trochę język szwedzki. W maszynowni nadzór pełnił por. mar. Tadeusz Męczyński, a pozostali oficerowie pełnili służbę obserwacyjną na pokładzie, kpt. mar. Konrad Sawicz-Korsak na

39 J. Milisiewicz, op. cit., s. 89-90; J. Pertek, Jak przerywano blokadę na Helu, „Morze”, 10/1959, s. 28; idem, Ryzykowna eskapada. Jak ścigacz „,Batory” forsowat blokadę Helu, „Litery”, 11/1964, s. 2; idem, Wielkie dni małej floty, Poznań 1987, s. 156-157; Spis załogi „Batorego” sporządzony przez kpt. Milisiewicza w Klintehamn (Izba Pamięci Jerzego Pertka w Bibliotece Raczyńskich); Polska flyktingar från Hela till Gotland, „Gotlands Allehanda” z 3 X 1939 r.; „Batory” i gotländska farvatten, „Gotlands Allehanda” z 6 X 1939 r. W relacji W. Salamona pod datą 1 XI 1939 r. znajduje się informacja, że w grupie przybyłych uciekinierów z kutra pościgowego „Batory”, znajdował się oficer o nazwisku Jankisz. Zob. I. Bieniecki, op. cit., s. 76.

40 B. Żarczyński, Wspomnienia ze stużby w 2 Morskim Plutonie Żandarmerii na Helu, w: Ostatnia Reduta. Sprawozdania z walk i relacje obrońców Helu, red. R. Witkowski, Gdańsk 1973, s. 301. Jak wspomina por. mar. obs. K. Szczęsny z Morskiego Dywizjonu Lotniczego, który szykował się do ucieczki na jednym z kutrów rybackich, zdołał on przekonać por. mar. A. Górskiego z „Batorego” do ucieczki razem z nim na kutrze rybackim „Hel 117”„Adela”. Por. mar. A. Górski zostawił mu swój płaszcz podbity futrem i pobiegł zabrać swoje rzeczy ze ścigacza, ale popłynął jednak na „Batorym”. Por. mar. obs. K. Szczęsny został z jego płaszczem, który przydał się w niewoli. Zob. A. Gosk, Zagłada Morskiego Dywizjonu Lotniczego, „Morze”, 9/1984, s. 31. Na ucieczkę „Batorym” nie zdecydował się I motorzysta J. Lis ze stałej załogi ścigacza, ponieważ nie chciał zostawić rodziny. Po kapitulacji RU Hel został rozstrzelany 17 XI 1939 r. Zob. T. Falba, Rodzinny kuter pościgowy. Lisowie na Batorym, „Nasze Morze", 10/2010, s. 36-37. Na pokładzie ścigacza zamierzał także uciekać kpr. żand. A. Seroka, ale zrezygnował w ostatniej chwili. Zob. A. Seroka, 32 dni obrony Helu, Olsztyn 1979, s. 160-163. Propozycję ucieczki „Batorym” odrzucił kpt. Antoni Kasztelan ze sztabu kadm. J. Unruga. 14 XII 1942 r. został zgilotynowany przez Niemców w Królewcu. Zob. S. Kudela, Kapitan Antoni Kasztelan (1898-1942), „Biuletyn Historyczny”, 17/2001, s. 171; J. Łubkowski, Kapitan Antoni Kasztelan - tragiczna postać września, „Biuletyn Historyczny”, 20/2005, s. 267.

41 J. Milisiewicz, op. cit., s. 85. 
dziobie, a kpt. mar. Eligiusz Ceceniowski, por. mar. Alfons Górski i ppor. mar. Mieczysław Tarczyński po obu burtach i na rufie. Początkowo „Batory” płynął kursem równoległym do Mierzei Wiślanej, gdzieś poza Brüsterort, a po dwóch godzinach, gdy minięto Piławę, kpt. Jerzy Milisiewicz zmienił kurs na północno-zachodni na Hoburg. Paliwa do silników benzolowych pozostało jeszcze wtedy na co najmniej Io godzin. O godz. 23.00 obserwatorzy na ścigaczu zauważyli światła z lewej burty z odległości wystarczającej na zmianę kursu na $90^{\circ}$ i pozostanie niezauważonym. Następnie, gdy zauważona jednostka - prawdopodobnie okręt wojenny - odpłynęła, „Batory” wykonał zwrot $180^{\circ} \mathrm{w}$ lewo za jej rufą na dawny kurs. Na szczęście kuter płynął bez świateł rozpoznawczych. O północy ponownie zauważono światła obcego okrętu, ale również zdążono go wyminąć. O godz. 8.00 motorzysta ścigacza mat Roch Kaźmierczak zameldował, że benzolu pozostało tylko jeszcze na dwie godziny rejsu, w wyniku czego kpt. Jerzy Milisiewicz wydał rozkaz uruchomienia silnika Diesla. Mimo pewnych trudności mat Roch Kaźmierczak zdołał uruchomić silnik Diesla. Zapas ropy pozwalał płynąć ścigaczowi na tym silniku Io godzin ${ }^{42}$.

Mar. rez. Witold Hubert wspomina w swojej relacji o uczuciu głodu i pragnienia, które towarzyszyło załodze „Batorego”:

Jesteśmy solidnie głodni, a przede wszystkim szalenie doskwiera pragnienie. Próbuję na prymusie zrobić kawę. Tak, ale wodę mamy tylko ta, po której płyniemy. Co z tego wyszło, to trudno nazwać, lecz zmoczeni, zmarznięci i spragnieni wypiliśmy po kilka łyków tego napoju $u^{43}$.

W tym czasie pogoda się pogorszyła, wzrosła siła wiatru i wysokość fali, a „Batory” płynący już kilkanaście godzin powinien był według części załogi znaleźć się w Szwecji. Żądali oni zmiany dotychczasowego kursu, który uważali za błędny. W wyniku sondowania dna okazało się, że ścigacz znajduje się na Ławicy Hoburg, a więc kurs był właściwy. Wtedy stanęły silniki benzolowe i „Batory” płynął tylko na silniku Diesla. Wkrótce pogoda się poprawiła, a ścigacz znalazł się o godz. I2.0044 na trawersie latarni morskiej znajdującej się na południowym cyplu Gotlandii. Po opłynięciu cypla skierował się do Visby na zachodnim wybrzeżu wyspy. Gdy „Batory” znajdował się niedaleko wysepki Karlsö tuż przed godz. I5.00 zauważono z jego pokładu niemiecki okręt, ale w tym momencie przypłynął szwedzki torpedowiec „Rangun”, który poprowadził polską jednostkę do portu Klintehamn, gdzie zakotwiczyła o godz. I5.30, kończąc swoją wyprawę przez Bałtyk do Szwecji ${ }^{45}$.

\footnotetext{
42 W. Hubert, Mój udział w walkach obronnych na Helu 1939 r. Ucieczka do Szwecji na motorówce „,Batory” (AMMW, sygn. 449, s. 2-3); J. Milisiewicz, op. cit., s. 86-87; J. Pertek, Jak przerywano blokadę na Helu, „Morze”, 10/1959, s. 26, 28; idem, Ryzykowna eskapada. Jak ścigacz „,Batory” forsowat blokadę Helu, „Litery”, 11/1964, s. 2-3; idem, Wielkie dni matej floty, Poznań 1987, s. 157-158.

43 W. Hubert, op. cit., s. 3.

44 Według relacji W. Huberta około godz. 12.00 „Batory” został zauważony przez niemiecki samolot, który po zatoczeniu nad kutrem dwóch kół odleciał. Zob. W. Hubert, op. cit., s. 3.

45 Ibidem, s. 3; K. Madeja, Ucieczka przez noc, „Panorama”, 1/1987, s. 12-13; J. Milisiewicz, op. cit., s. 85-86; J. Pertek, Jak przerywano blokadę na Helu, „Morze”, 10/1959, s. 26; idem, Ryzykowna eskapada. Jak ścigacz „,Batory” forsowat blokadę Helu, „Litery”, 11/1964, s. 3; idem, Wielkie dni małej floty, Poznań 1987, s. 158-159; W. Steyer, Zagon kutra motorowego „Batory”, „Żołnierz Polski”, 35/1946, s. 9. Nie wiadomo dokładnie, czy niemiecki okręt, którym miało być awizo „Grille”, otworzył ogień i czy towarzyszyły mu niemieckie ścigacze. Zob. W. Hubert, op. cit., s. 3; K. Madeja, op. cit., s. 13; J. Pertek, Ryzykowna eskapada. Jak ścigacz „,Batory” forsowat blokadę Helu, „Litery”, 11/1964, s. 3; W. Steyer, op. cit., s. 9.
} 
Kpt. Jerzy Milisiewicz po zejściu na ląd natychmiast porozumiał się telefonicznie z posłem polskim w Sztokholmie, który jednak w żaden sposób nie był w stanie pomóc załodze ścigacza. Dowódca torpedowca „Ragnar” kpt. Ström zaprosił kpt. Jerzego Milisiewicza wraz z jednym oficerem Polskiej Marynarki Wojennej na kolację, podczas której tłumaczył przepisy dotyczące internowania. Po kolacji kpt. Jerzy Milisiewicz wrócił na pokład ścigacza, który z portu miał wyprowadzić por. mar. Tadeusz Męczyński. Około godz. I8.30 podczas odcumowania doszło do złamania rufowego masztu flagowego i uszkodzenia śruby od silnika Diesla w wyniku najechania na kamienną mieliznę. Ścigacz próbowano zepchnąć na głębszą wodę za pomocą lin przerzuconych z rufy na brzeg i ciągniętych przez Szwedów zgromadzonych w porcie. Gdy to się wreszcie udało, po dwóch obrotach zatrzymała się śruba. W wyniku tego zdarzenia i braku możliwości szybkiej naprawy po upływie 24 godzin ścigacz został internowany, mimo że nie był okrętem wojennym. Wcześniejsze rozmowy z władzami szwedzkimi w sprawie paliwa na przejście „Batorego” do Visby i dalej nie odniosły żadnego skutku. Ponadto władze szwedzkie otrzymały listę załogi ścigacza z adnotacją, że właścicielem jednostki jest Polska Marynarka Wojenna ${ }^{46}$ i kpt. Jerzy Milisiewicz musiał wyjaśniać to nieporozumienie. 3 października 1939 r. o godz. 6.00 „Batory” opuścił Klintehamn na holu, płynąc za torpedowcem „Ragnar” do Visby, gdzie został wzięty na slip, aby można było dokonać naprawy uszkodzonej śruby. Trzej celnicy i dwaj urzędnicy cywilni oraz mar. rez. Witold Hubert zostali zwolnieni. Natomiast resztę załogi internowano47.

W dniu I listopada I939 r. ścigacz „Batory” został przeprowadzony na holu przez dozorowiec „Snapphanen” do Vaxholmu, gdzie znajdowały się wszystkie internowane w Szwecji polskie jednostki jak „Dar Pomorza” i okręty podwodne ORP „Sęp”, ORP „Ryś” i ORP ,Żbik" ${ }^{48}$.

Niepowodzeniem zakończyła się próba przerwania niemieckiej blokady Helu przez dwa kutry rybackie, które opuściły po godz. 20.00 port rybacki Hel już po wypłynięciu ścigacza „Batory”. Jeden z nich kuter, „Hel II7” - „Adela”49, którego współwłaścicielami byli ppor. mar. rez. Józef Lipski i rybak Szewczyk, zabrał większość oficerów marynarki, która zdecydowała się na tę ryzykowną wyprawę. Wśród nich znaleźli się kmdr por. Stefan de Walden, kmdr por. rez. Adam Mochuczy, kmdr ppor. Kazimierz Szalewicz i kmdr ppor. Jan Łuszczkiewicz oraz kpt. mar. Józef Chodakowski, kpt. mar. rez. Mieczysław Jacynicz, kpt. mar. pil. Aleksander Krawczyk, kpt. mar. Bohdan Mańkowski ${ }^{50}$, kpt. mar. Wiktor Pstruszeński, kpt. mar. Józef Puzyna i kpt. mar. Kazimierz Sulisz, a także por. mar. Zygmunt

\footnotetext{
46 Spis załogi „,Batorego” sporządzony przez kpt. Milisiewicza w Klintehamn (Izba Pamięci Jerzego Pertka w Bibliotece Raczyńskich).

47 J. Milisiewicz, op. cit., s. 88-90; J. Pertek, Jak przerywano blokade na Helu, „Morze”, 10/1959, s. 28; idem, Ryzykowna eskapada. Jak ścigacz „,Batory” forsowat blokadę Helu, „Litery”, 11/1964, s. 3; idem, Wielkie dni matej floty, Poznań 1987, s. 159-160. W szwedzkim artykule zamieszczonym w internecie podana jest informacja, że jednak dostarczono na pokład „Batorego” $15 \mathrm{~kg}$ paliwa do silnika Diesla. Ponadto próby ściągnięcia kutra z mielizny odbywały się w świetle reflektorów stojącej na nabrzeżu taksówki. Zob. M. Lundgren, R. Wróblewski, Polska Batorys flykt till Gotland 1939, http://www.tjelvar.se/flyktingar/polen-2.htm (20 09 2013).

48 J. Pertek, Ryzykowna eskapada. Jak ścigacz „,Batory” forsowat blokadę Helu, „Litery”, 11/1964, s. 3; idem, Wielkie dni małej floty, Poznań 1987, s. 160.

49 „Hel 117” - „Adela” - kuter drewniany zbudowany w 1938 r. w stoczni Rybackiej w Gdyni, długość 19,10 m, szerokość 5,15 m, data rejestracji 10.03.1938 r. Zob. B. Huras, M. Twardowski, op. cit., s. 32.

50 Akta osobowe Bohdana Mańkowskiego (Archiwum Urzędu do Spraw Kombatantów i Osób Represjonowanych, sygn. K-6.011.188, s. 4,7).
} 
Grabowski, por. mar. pil. Zdzisław Juszczakiewicz, por. mar. Wacław Krzywiec, por. mar. obs. Kazimierz Szczęsny i por. inż. Józef Bieńkiewicz. Na kutrze znaleźli się także: bos. pchor. inż. Zygmunt Kiciński, współwłaściciel kutra ppor. mar. rez. Józef Lipski oraz kilku podoficerów i marynarzy, których nazwisk nie udało się ustalić. Dowódcą kutra został kmdr por. Stefan de Walden.

Natomiast na drugim kutrze, prawdopodobnie był to „Hel III” - „Aleksander”`, znaleźli się kpt. mar. Józef Giertowski i kpt. mar. Józef Wierzchowski, ppor. mar. Michał Anaszkiewicz, ppor. mar. Julian Czerwiński, ppor. mar. Stanisław Leszczyński, ppor. mar. Władysław Pławski, ppor. mar. Ludwik Zaborski, ppor. mar. Jerzy Żytowiecki oraz ppor. mar. rez. Tadeusz Jasicki i ppor. mar. rez. Michał Niczko. Ponadto na kutrze znajdowało się około 20 podoficerów i marynarzy. Dowódcą kutra został wybrany przez uciekających ppor. mar. rez. Michał Niczko, doświadczony oficer $z$ floty handlowej ${ }^{52}$.

Por. mar. obs. Kazimierz Szczęsny wspomina w swojej relacji, jak dowiedział się o planowanej ucieczce kutrami:

W przeddzień kapitulacji półwyspu przybyt do nas łącznik, wręczajac mi pisemne polecenie stawienia się w Helu, gdyż planowana jest ewakuacja części oficerów na kutrach. Polecono przebrać się w cywilne rzeczy, upodabniajace nas do rybaków. Cudacznie przebrany, ale ze swoim lotniczym skórzanym płaszczem $i w$ czapce zameldowałem się na Helu. Na miejscu byty już grupy szykujących się do ewakuacji. Dostałem przydział na zmobilizowany kuter, własność Józia Lipskiego ${ }^{53}$.

Natomiast kpt. mar. rez. Mieczysław Jacynicz wspomina w swojej relacji, jak zamierzano przedrzeć się przez linie niemieckiej blokady morskiej polskiego Wybrzeża:

Plan ucieczki byt następujacy: aby ominąć normalnie rejony patrolowane przez niemieckie okręty, mieliśmy płynać początkowo w stronę Piławy, potem zmienić kurs na północ. Godziny oczekiwania nocy wlokty się niemiłosiernie. Zwiększało to podniecenie i nerwy. Ci koledzy, którzy z nami nie ptynęli, odradzali jazdę, ttumacząc nam, że to szaleństwo włażenie śmierci w ramiona. Nic nie wskórali. Było nam wszystko jedno, a może się $u d a ?^{54}$.

Potwierdza to por. mar. obs. Kazimierz Szczęsny, który wspomina, że dowodzący kutrem „Hel II7” - „Adela”, kmdr por. Stefan de Walden zdecydował o wypłynięciu na środek Zatoki Gdańskiej, a następnie skierowaniu się na północ w kierunku Szwecjis5.

${ }^{51}$ „Hel 111”- „Aleksander” - kuter drewniany zbudowany w 1938 r. w stoczni Rybackiej w Gdyni, dhugość 19,10 m, szerokość 5,15 m, data rejestracji 10.03.1938 r. Zob. B. Huras, M. Twardowski, op. cit., s. 32.

52 J. Czerwiński, Ucieczka ewazyjna z Helu. Na kutrach rybackich, dla uniknięcia niewoli (Izba Pamięci Jerzego Pertka w Bibliotece Raczyńskich, s. 1); idem, Marynarski podkop. (Wspomnienia wojenne oficera Marynarki Wojennej), „Przegląd Morski”, 1/1989, s. 59-60; J. Pertek, Jak przerywano blokadę na Helu, „Morze”, 10/1959, s. 26; idem, Wielkie dni małej floty, Poznań 1987, s. 156; idem, Mała flota wielka duchem, Poznań 1989, s. 115-116. Według J. Pertka na jednym z kutrów znajdował się ppor. art. rez. inż. Sławosz Borowski. Zob. J. Pertek, Mała flota wielka duchem, Poznań 1989, s. 116.

53 A. Gosk, Zagłada Morskiego Dywizjonu Lotniczego, „Morze”, 9/1984, s. 31.

54 Cyt. za: J. Pertek, Mała flota wielka duchem, Poznań 1989, s. 116-117.

55 A. Gosk, op. cit., s. 31. Płynący drugim kutrem ppor. mar. rez. T. Jasicki twierdzi, że po wypłynięciu za półwysep od razu skierowano się na północ na wyspę Gotland. Tę wersję potwierdza dowódca trałowca „Nautilus”, lokalizując miejsce zatrzymania kutrów na północ od cypla Helu. Zob. T. Jasicki, Ze wspomnień, w: Ku chwale 
Przebieg wyprawy do momentu zatrzymania przez niemieckie okręty wspomina kpt. mar. rez. Mieczysław Jacynicz:

Noc zapowiadała się jasna, ale łudziliśmy się, że jakieś chmurki zakryja , tysego”. Na kutrze byt komplet. W ciszy wyruszyliśmy po wolność. Mimo zdenerwowania na kutrze panowała idealna zgoda i dyscyplina... Ptynęliśmy zgodnie z planem. Na niebo nie wypełzła żadna, nawet koślawa chmureczka. Gdzieś w okolicy Piławy w momencie zwrotu na pótnoc zauważyliśmy jednostki wojenne. Zbliżały się do nas wyraźnie, a my zrozumieliśmy, że to byt ostatni etap ucieczki. I rzeczywiście, bowiem po doptynięciu okazało się, że to Niemcy ${ }^{56}$.

Kutry płynęły z prędkością 8 węzłów i do momentu zatrzymania przepłynęły około 40 mil. Około godz. I.oo w nocy 2 października zostały zauważone i zatrzymane przez dwa niemieckie trałowce „Nautilus” i „Pelikan”, które płynęły z Ustki do Piławy. Niemcy zauważyli podejrzane cienie po lewej burcie, czyli od strony pełnego morza, podejrzewając, że może to być okręt podwodny. Po zbliżeniu się na odległość Iooo m stwierdzili, że są to dwa kutry rybackie i wystrzelili rakietę rozpoznawczą. Ponieważ nie było odpowiedzi, trałowce podpłynęły bliżej57.

Moment ten tak wspomina dowódca trałowca „Nautilus”:

Na pokładzie kutra nic nie widać. Wydaje się, jakby ludzie położyli się tam na pokładzie. My byliśmy teraz tak blisko, że mogliśmy wołać do nich. Próbuję przez tubę, ale ponownie bez odpowiedzi.

- Stoppen Sie sofort! - krzyczę do nich ponownie.

Kutry uciekaja, jak tylko moga. Widzę teraz jednego człowieka stojącego za rura wydechową, który polską czapka oficerska próbuje zasłonić iskry, które sypia się z rury wydechowej. Jeśli te chłopaki nie chca w ogóle niczego słyszeć, to musi wobec tego przemówić karabin maszynowy!

- Tak-tak-tak-tak!

Karabin maszynowy terkoce, białe nitki amunicji smugowej sypia się za tylnym kutrem. Padaja daleko za masztem w fale. Teraz ostatni kuter staje $w$ dryfie, a drugi idzie chwile później jego śladem ${ }^{58}$.

Natomiast tak wyglądało zatrzymanie polskich kutrów widziane z trałowca „Pelikan”:

Dowódca już zawraca i z całą szybkościa rusza ku podejrzanym jednostkom, towarzysz postępuje za nim. Dzwonki alarmowe przeraźliwie dzwonia na obu okrętach, petne oczekiwania załogi czekaja na swych pozycjach bojowych na dalsze rozkazy. Już przedni okręt daje obu statkom rozkaz zastopowania. Nie zważaja na to i ida dalej, ale

\footnotetext{
bandery, red. J. Miciński, Warszawa 1992, s. 102 i H. Steen, Blaue Jungen schlagen Polen: erlebnisse von den Kämpfen unserer Truppen um die Danziger Bucht im Blitzkrieg, Stuttgart 1940, s. 23.

56 Cyt. za: J. Pertek, Mała flota wielka duchem, Poznań 1989, s. 117.

57 T. Jasicki, op. cit., s. 102; H. Steen, op. cit., s. 23; S. de Walden, K. de Walden-Gałuszko, W. Szarski, ORP Wicher i jego dowódca, ,Zeszyt Helski”, 18/2013, s. 74-75. Według relacji T. Jasickiego okręty niemieckie utrzymywały 3 linie patrolowania. Ostatnia linia była patrolowana tej nocy przez trałowce „Nautilus” i „Pelikan”, które płynęły z przeciwnych kierunków. Zob. T. Jasicki, op. cit., s. 102.

58 H. Steen, op. cit., s. 23-24. Ostrzelanie kutra po dowództwem ppor. mar. rez. M. Niczko potwierdza ppor. mar. rez. T. Jasicki. Zob. T. Jasicki, op. cit., s. 102.
} 
kilka sekund później pociski świetlne padaja tak celnie tuż przed dziobem pierwszej jednostki, że teraz wreszcie obie staja $a^{59}$.

W chwili zatrzymania przez niemieckie trałowce na polskich kutrach pozbywano się broni. Na kutrze „Hel III” - „Aleksander” wyrzucono za burtę karabiny, a ppor. mar. rez. Tadeusz Jasicki wrzucił do wody pistolet VIS, który otrzymał kilka dni wcześniej od swojego kolegi ze szkoły kpt. Wierzbowskiego. Natomiast na drugim kutrze por. mar. Wacław Krzywiec pozbył się granatów, które trzymał w walizce zabranej z Helu. Następnie do kutra „Hel II7” - „Adela” dopłynął trałowiec „Pelikan” z prawie całą załogą stojącą na pokładzie z bronią wymierzoną w Polaków, a do kutra „Hel III” - „Aleksander” podszedł trałowiec „Nautilus”. Kutry zostały przeszukane, a polscy oficerowie, podoficerowie i marynarze zostali zrewidowani po przejściu na pokłady trałowców. Po wzięciu kutrów na hol okręty skierowały się do Piławy, do której dotarły 2 października rano ${ }^{60}$.

Wyjaśnienia wymaga kwestia liczby oficerów i marynarzy, którzy próbowali uciec na obu kutrach. Według H. Steena, niemieckiego korespondenta wojennego, na pierwszym kutrze znajdowało się Io oficerów marynarki i I3 inżynierów, na drugim I7 oficerów i Io inżynierów, a zatem do niewoli trafiło 27 oficerów i 23 inżynierów. Oczywiście podana liczba inżynierów jest nieprawdziwa. Natomiast F.O. Busch, drugi korespondent wojenny, podaje liczbę 17 wyższych oficerów marynarki, 2 oficerów - inżynierów oraz 6 podoficerów i marynarzy zatrzymanych na pierwszym kutrze. Na drugim zatrzymano $w$ przybliżeniu taka sama zdobycz ${ }^{61}$. Ppor. mar. rez. Tadeusz Jasicki wspomina, że na kutrze, którym płynął, znajdowało się 37 osób. Ppor. mar. Julian Czerwiński w swojej relacji podaje, że na kutrze „Hel II7” - „Adela”, znajdowało się I7 oficerów, kilku podoficerów i kilku marynarzy, a na drugim Io oficerów i około 20 podoficerów i marynarzy. Według kpt. mar. rez. Mieczysława Jacynicza na kutrze „Hel II7” - „Adela”, znajdowało się I8 ludzi. Kmdr por. Stefan de Walden podaje w swoim oświadczeniu złożonym II stycznia I949 r., że wraz z nim podjęło próbę ucieczki około 50 oficerów, podoficerów i marynarzy. Podobne oświadczenie złożył I2 stycznia 1949 roku kpt. mar. Jerzy Żytowiecki. Według meldunku zapisanego w dzienniku działań bojowych pancernika „Schleswig-Holstein” o godz. 6.00 doprowadzone zostały do Piławy dwa kutry rybackie z 52 jeńcami wśród których znajdowało się 29 oficerów.

W dzienniku działań wojennych dowódcy niemieckich sił morskich w rejonie Zatoki Gdańskiej kadm. Huberta Schmundta znajduje się pod datą 2 października 1939 r. zapis o ucieczce w nocy 52 żołnierzy w tym 29 oficerów. Podpis pod zdjęciem jednego z kutrów doprowadzonych do Piławy informuje o wzięciu do niewoli 27 ludzi. Natomiast komunikat nr 32 Oddziału Obrony Kraju OKW o położeniu na froncie na dzień 2 października 939 roku informuje o nieudanej próbie ucieczki 53 żołnierzy polskich, w tym 29 oficerów na dwóch

59 Cyt. za: J. Pertek, Mała flota wielka duchem, Poznań 1989, s. 119.

60 A. Gosk, op. cit., s. 31; J. Pertek, Porucznik z kuferkiem granatów, „Ziemia i Morze”, 10/1957, s. 6; idem, Mała flota wielka duchem, Poznań 1989, s. 123-124; T. Jasicki, op. cit., s. 102. Według relacji T. Jasickiego, trałowce $\mathrm{z}$ ciągniętymi na holu kutrami wpłynęły do Piławy już około godz. 8.00., a według zapisu w dzienniku bojowym pancernika „Schleswig-Holstein” miało to miejsce jeszcze wcześniej o godz. 6.00. Zob. T. Jasicki, op. cit., s. 102; J. Żebrowski, Zanim poddat się Hel. Niemiecki dokument z 1939 roku. Dziennik działań bojowych pancernika „Schleswig-Holstein” od 24.08 do 02.10.1939 r., Łódź 2003, s. 150.

${ }^{61}$ F.O. Busch, Akten des Seekriegs, Berlin 1940, s. 189. 
kutrach rybackich ${ }^{62}$. Należy więc przyjąć, że na obu kutrach próbowało uciec 50-52 oficerów, podoficerów i marynarzy w tym 29 oficerów.

Po przybyciu do Piławy, jeńcy z obu kutrów zostali zakwaterowani w Koszarach Artylerii Morskiej Skagerrak, gdzie byli przyzwoicie traktowani. Następnie oficerowie zostali oddzieleni od podoficerów i marynarzy. Komendantem grupy oficerów został kpt. mar. Bohdan Mańkowski biegle posługujący się językiem niemieckim. Po upływie dwóch tygodni jeńcy zostali przewiezieni samochodami do Klein Dexen w Prusach Wschodnich. W miejscowości tej przebywali około dwóch tygodni, skąd zostali przetransportowani do pobliskiego Stablack, a później koleją do Riesenburga. Na początku listopada 1939 r. grupa oficerów trafiła w końcu do Oflagu XVIII A w Lienzu nad Drawą ${ }^{63}$.

Niepowodzeniem zakończyła się również próba wydostania się z portu rybackiego na Helu na motorówce Straży Granicznej „Kaszub”" ${ }^{4}$. Próbę tę podjęło w nocy z I na 2 października I939 r. kilku oficerów, około I5 żandarmów oraz marynarze z różnych jednostek.

Grupa marynarzy, w skład której wchodzili m.in. bosman podchorąży Stanisław Żochowski z załogi kanonierki ORP „Generał Haller”, Jakub Marzec, Wacław Wolny i Eugeniusz P. Gumiński, przybyła przed północą I października I939 r. do portu rybackiego na Helu w poszukiwaniu kutra, na którym można było podjąć próbę ucieczki. Zauważyli oni motorówkę Straży Granicznej „Kaszub” obsadzoną przez oficerów i żandarmów z 2 Morskiego Plutonu Żandarmerii, wśród których znajdowali się kpr. Kazimierz Jakubowski, kpr. Alojzy Sadecki, kpr. Czesław Skowroński i kpr. Jan Gulczyński. Nie potrafili oni uruchomić silnika.

62 F.O. Busch, op. cit., s. 189; J. Czerwiński, Ucieczka ewazyjna z Helu. Na kutrach rybackich, dla uniknięcia niewoli (Izba Pamięci Jerzego Pertka w Bibliotece Raczyńskich, s. 1); A. Drzewiecki, Adam, Aleksander i Borys Mochuczowie. W stużbie Polskiej Marynarki Wojennej, Toruń 2005, s. 166-167; T. Jasicki, op. cit., s. 102; Z. Machaliński, Adam Mochuczy (1891-1953), pseudonim Pirat, kontradmirał Polskiej Marynarki Wojennej, dowódca Polskiej Marynarki Wojennej, dyrektor Szkoły Morskiej w Gdyni, prezes Rady Głównej Ligi Morskiej, kapitan żeglugi wielkiej, „Nautologia”, 2/1999, s. 26-27; R. Niczko, Ucieczka kutrów z Helu, „Morze Statki i Okręty”, 10/2010, s. 27; J. Pertek, Jak przerywano blokadę na Helu, „Morze”, 10/1959, s. 26; H. Steen, op. cit., s. 24, 26; Z. Wojciechowski, Dziennik działań wojennych kontradmirała Huberta Schmundta z 1939 r., „Biuletyn Historyczny”, 18/2003, s. 47; J. Żebrowski, op. cit., s. 150; Komunikat nr 32 Oddziału Obrony Kraju OKW o położeniu na froncie na dzień 2 października 1939 r., w: Wojna Obronna Polski 1939. Wybór źródet, red. E.J. Kozłowski, Warszawa 1968, s. 1001; R. Niczko pisze o różnicy w liczbie uciekających podoficerów i marynarzy, jaką podają J. Pertek i J. Czerwiński. Pierwszy z nich podaje, że było ich 20, a drugi pisze o 30 osobach. Zdaniem autora, przyczyną tej różnicy jest to, że R. Niczko opierał się prawdopodobnie na wspomnieniach J. Czerwińskiego opublikowanych w „Przeglądzie Morskim” w 1989 r., w których pisze o ponad 30 podoficerach i marynarzach, którzy dostali się do niewoli. Natomiast J. Pertek korzystał z wcześniejszej relacji J. Czerwińskiego, której maszynopis posiadał. W tej relacji J. Czerwiński pisze o około 20 podoficerach i marynarzach na kutrze „Hel 111” - „Aleksander” i kilku podoficerach oraz kilku marynarzach na drugim kutrze, którzy dostali się do niewoli. Zob. J. Czerwiński, Ucieczka ewazyjna z Helu. Na kutrach rybackich, dla uniknięcia niewoli (Izba Pamięci Jerzego Pertka w Bibliotece Raczyńskich, s. 1); idem, Marynarski podkop. (Wspomnienia wojenne oficera Marynarki Wojennej), „Przegląd Morski”, 1/1989, s. 60; R. Niczko, Ucieczka kutrów z Helu, „Morze Statki i Okręty”, 10/2010, s. 27; idem, Ku wolności ucieczki z Wybrzeża 1939 r., „Zeszyt Helski”, 14/2012, s. 11; J. Pertek, Mała flota wielka duchem, Poznań 1989, s. 115.

63 J. Czerwiński, Ucieczka ewazyjna z Helu. Na kutrach rybackich, dla uniknięcia niewoli (Izba Pamięci Jerzego Pertka w Bibliotece Raczyńskich, s. 2); idem, Marynarski podkop. (Wspomnienia wojenne oficera Marynarki Wojennej), „Przegląd Morski”, 1/1989, s. 60; T. Jasicki, op. cit., s. 103.

64 „Kaszub” - motorówka patrolowa Straży Granicznej zbudowana w Stoczni Modlińskiej. Rozpoczęcie budowy nastąpiło na wiosnę 1931 r., a 7 maja 1932 r. motorówka była gotowa do prób odbiorczych. Wyporność 12,5 t. std. z ołowianym balastem, długość całkowita $14 \mathrm{~m}$, szerokość $3,1 \mathrm{~m}$, wysokość burty 1,4 m, zanurzenie $0,85 \mathrm{~m}$ ze stępką. Napęd 1 silnik 6 cylindrowy benzynowy Kermath o mocy 210/225 KM. Uzbrojenie 2 ckm Maxim 08 kal. 7,9 mm. Prędkość 12,5-13 węzłów. Załoga 3-4 ludzi. Zob. M. Kuligiewicz, Motorówki patrolowe typu „,Kaszub”, „Morze”, 4/1974, s. 37. 
W zamian za jego uruchomienie zgodzili się oni przyjąć na pokład grupę marynarzy. Gdy w końcu udało się uruchomić przy pomocy celników silnik, „Kaszub” wypłynął z portu i po opłynięciu cypla Półwyspu Helskiego skierował się na pełne morze w kierunku Szwecji. Po oddaleniu się o 3 mile od Półwyspu Helskiego marynarz przypadkowo pełniący funkcję motorniczego przestraszył się nadlatującego wodnosamolotu i chciał zwolnić do minimum, aby nie pozostawiać śladu torowego na wodzie. W wyniku tego zgasł motor, którego nie zdołano już ponownie uruchomić. Wodnosamolot nie zauważył motorówki i poleciał dalej, a fala zdryfowała „Kaszuba” w ciągu nocy w kierunku półwyspu i wyrzuciła na mieliznę w odległości około Ioo m od brzegu. Woda w tym miejscu sięgała do szyi i niedoszli uciekinierzy musieli dotrzeć do brzegu wpław ${ }^{65}$.

Należy wspomnieć o jeszcze jednej ucieczce, w której udział wzięło pięciu marynarzy z załogi stawiacza min ORP „Gryf”. Byli to mar. Tadeusz Kosidło, st. mar. Stanisław Celejewski, st. mar. Kazimierz Dzirba, st. mar. Józef Wojda i mar. Lucjan Białobrzeski. I października I939 r. o godz. 22.00 wypłynęli oni z portu wojennego na Helu w sześciowiosłowej łodzi będącej wcześniej na wyposażeniu stawiacza min ORP „Gryf”. Oprócz skrzyni granatów i 5 karabinów, każdy z nich zaopatrzył się w dwa komplety ubrań, dwa swetry i parę nowych butów tzw. saperek. W zależności od warunków atmosferycznych mieli płynąć do Szwecji przy wietrze zachodnim albo do Gdyni przy wietrze wschodnim. Po wypłynięciu okazało się, że będą płynęli pod żaglem do Gdyni. Po około czterech godzinach dopłynęli w okolice Babiego Dołu. Wcześniej przepłynął obok nich prawdopodobnie niemiecki trałowiec, ale ich nie zatrzymał. Kiedy znaleźli się blisko brzegu, wystrzelona przez Niemców raca na chwilę oświetliła teren. $Z$ łodzi zeszli do wody i przed dotarciem na brzeg wrzucili do wody karabiny i granaty, zabierając tylko lornetkę. Cały czas spodziewali się, że Niemcy otworzą ogień z karabinów maszynowych. Po dotarciu na brzeg i chwili odpoczynku, odłączając się od reszty, mar. Tadeusz Kosidło i mar. Lucjan Białobrzeski pomaszerowali w kierunku Gdyni. Po przejściu I,5 km brudni i przemoknięci zastukali w okno jednego z domów, ale nie zostali wpuszczeni do środka. Po kilku nieudanych próbach dostania się do jakiegoś domu, zostali wpuszczeni do domu państwa Małkowskich, gdzie po przebraniu się i spożyciu posiłku Pan Małkowski około 5 rano zawiózł ich bryczką do drogi na Koleczkowo. W końcu obaj dotarli do Starogardu Gdańskiego, w którym się rozstali. Mar. Tadeusz Kosidło dotarł do swojego rodzinnego miasta Puławy. Natomiast st. mar. Józef Wojda dostał się do niewoli, którą spędził w obozie koncentracyjnym Stutthof. Niestety nie wiadomo, co się stało z pozostałymi marynarzami ${ }^{66}$.

65 E.P. Gumiński, Prawda o „Kaszubie”, „Morze”, 11/1974, s. 37; A. Kiszkis, Ostatnia Reduta, „Express Wieczorny", 176/1987, s. 3; K. Mirowski, Moje wspomnienia ze stużby w Marynarce Wojennej. Udział w obronie Helu (AMMW, sygn. 341, s. 9-10); K. Mirowski, Wspomnienia z udziału w obronie Helu (AMMW, sygn. 815, s. 7); B. Żarczyński, Działalność 2 Morskiego Plutonu Żandarmerii na Helu w wojnie polsko-niemieckiej 1939 r. Alfabetyczny spis osób wystepujących w relacji. (Zbiory Specjalne Biblioteki Naukowej Wojskowego Biura Badań Historycznych, sygn. II/2/88, s. 1-2, od 2010 r. w Centralnym Archiwum Wojskowym); B. Żarczyński, Wspomnienia ze stużby w 2 Morskim Plutonie Żandarmerii na Helu, w: Ostatnia Reduta. Sprawozdania z walk i relacje obrońców Helu, red. R. Witkowski, Gdańsk 1973, s. 300; S. Żochowski, Działania kanonierki „,Gen. Haller” w kampanii wrześniowej (AMMW, sygn. 64, s. 31-32). Według B. Żarczyńskiego niedoszłych uciekinierów przewieźli łódkami na ląd marynarze z załogi 21 baterii artylerii plot. wchodzącej w skład 2 Morskiego Dywizjonu Artylerii Plot. Zob. B. Żarczyński, op. cit., s. 300.

66 Informacje oparte na podstawie fragmentów relacji T. Kosidły zamieszczonych w: M. Borowiak, ORP Gryf. Największy okręt bojowy Polskiej Marynarki Wojennej, Warszawa 2010, s. 224-226. 
Jeszcze przed wstrzymaniem działań wojennych i podjęciem rozmów w sprawie kapitulacji RU Hel została podjęta próba ucieczki łodzią rybacką przez sześciu żołnierzy. Prawdopodobnie nad ranem I października opuścili oni Półwysep Helski, ale zostali zatrzymani przez niemiecki trałowiec „M-I26”. Meldunek o tym zdarzeniu nadany przez radiostację trałowca został odebrany o godz. 8.II na okręcie liniowym ,Schleswig-Hostein”. Dowódca Sił Morskich w Zatoce Gdańskiej kadm. Hubert Schmundt wydał rozkaz dostarczenia jeńców do Nowego Portu ${ }^{67}$.

Niewiele wiadomo o próbie ucieczki łodzią do Szwecji podjętą przez kilku ludzi prawdopodobnie 2 października podczas zajmowania Półwyspu Helskiego przez oddziały niemieckie. Łódź została najpierw zauważona przez niemiecki samolot, a następnie po około dwóch godzinach zatrzymana przez niemiecki okręt. Uciekinierzy zostali przewiezieni na Oksywie, a po około trzech tygodniach do Gdańska. Znajdujący się w tej grupie Stefan Rytczak trafił w lutym lub marcu 1940 r. do obozu koncentracyjnego Stutthof. Nie wiadomo, co się stało z pozostałymi uczestnikami ucieczki ${ }^{68}$.

W okresie I IX-2 X I939 r. zakończyły się powodzeniem cztery próby przedarcia się drogą morską przez niemiecką blokadę polskiego Wybrzeża do państw neutralnych. W sumie na pokładach jachtu „Strzelec II”, duńskiego kutra rybackiego, kutra „Gdy 55” - ,Albatros” i kutra pościgowego Straży Granicznej „Batory” przedarło się 34 ludzi. Część z nich zasiliła później Polskie Siły Zbrojne na Zachodzie, kontynuując walkę z Niemcami. Należy podkreślić, że udane próby wydostania się $\mathrm{z}$ Wybrzeża były podejmowane zazwyczaj podczas trudnych warunków atmosferycznych, które jednak sprzyjały uniknięciu spotkania z niemieckimi okrętami patrolującymi wody w pobliżu polskiego Wybrzeża. Próby te podejmowane były bez wcześniejszego długiego planowania i przygotowywania, a jednak dzięki odwadze, pomysłowości i wyszkoleniu biorących w nich udział ludzi zakończyły się powodzeniem.

\section{Efforts of crossing the German blockade of Polish coast by sea 1 IX - 2 X 1939 Summary}

The article presents the attempts of Polish coast defenders' to get through to neutral countries by sea during military operations in September and October 1939. These efforts were made in spite of the German blockade of Polish coast by Kriegsmarine ships and Luftwaffe planes. This subject hasn't been widely featured yet using the reports of coast defenders kept in Polish and foreign archives. The goal of this article is the systematization of knowledge about these facts, presentation of characters of sailors, soldiers and civilians, who didn't want to go into captivity. Some of them were going to continue their struggle in Polish Armed Forces in the West.

Keywords: Escape, keelboat, Hel Peninsula, yacht, Batory

Nota o Autorze: Piotr Sykut (ur. w 1973 r. w Warszawie), historyk wojskowości, absolwent Wydziału Historycznego Uniwersytetu Warszawskiego. Zajmuje się najnowszą historią powszechną, historią wojskowości, w tym Polskiej Marynarki Wojennej z lat I9I8-I945, oraz obroną Wybrzeża w I939 r. Pracownik Urzędu m. st. Warszawy.

67 Z. Wojciechowski, op. cit., s. 44-45; J. Żebrowski, op. cit., s. 144.

68 S. Rytczak, Relacja (Archiwum Muzeum Stutthof, t. XV, s. 1-2). 